\title{
Implication of Interdisciplinary Team Teaching of an ESP Course
}

\author{
Larisa Maletina
}

Yuliya Karmanova

\author{
National Research Tomsk Polytechnic University, Lenin Avenue, 30, Tomsk, Russia \\ Email:Imaletina@mail.ru, kosmosila@inbo.ru
}

\author{
Valeriya Kashpur \\ National Research Tomsk State University, Lenin Avenue, 36, Tomsk, Russia \\ Email: valkashpur@inbox.ru
}

\section{Doi:10.5901/mjss.2015.v6n5p556}

\section{Abstract}

This paper aims to discuss the practical experience of "English for specific purposes" (ESP) course team teaching at National Research Tomsk Polytechnic University in Russia. The analysis of the basic concepts determining the team teaching environment, as well as the model in which it can be implemented, are presented herein. The major focus is the effectiveness of teaming of ESP course in enhancing academic and research achievements to meet students' needs. The conclusion of this paper highlights the benefits and challenges of the suggested model, and addresses the question of whether it can take place in ESP courses in the Russian universities.

Keywords: collaboration, co-operation, ESP, team teaching model

\section{Introduction}

A continuous process of technology renewal in the context of modern industry raises high demands on the training of engineering graduates. Engineers must possess essential technical skills in order to apply proven techniques and procedures to the solution of professional engineering problems. In the increasingly internationalized world, engineers are also required to take responsibility for intercultural cooperation in the professional sphere. They face various situations where they are expected to effectively communicate engineering information verbally, graphically, and in writing. In other words, they should, "Be literate in information and communication technologies, coupled with associated skills, and be able to keep abreast with new developments... (Grebet et al., 2004)."

Nonetheless, excellent technical skills do not guarantee engineering graduates will automatically be able to communicate effectively in an international environment. In view of the above, it becomes obvious that to perform efficiently in the workplace, engineering graduates must have a balance of both technical and non-technical skills. The latter includes communication skills that give an engineer the opportunity to fully work with foreign information sources, examine new world technologies, and interact effectively in professional and everyday environment.

A significant role in the training of perspective engineers with a high level of communication skills belongs to language education. Traditionally, the foreign language teaching in Russian universities had been aimed at the development of reading skills on the basis of professionally-oriented texts and their translation, mostly using dictionaries (Challenges of Higher Technical Education, 2001). Nowadays in Russian universities, ESP is generally accepted as the concept of teaching technical language in communication. The term "technical language" has a specific meaning within ESP. It refers to the specialized language which professionals use to communicate with each other.

ESP teaching is basically built on the assessment of students' outcomes and the aims for which English is required. Moreover, ESP combines both specific discipline knowledge and language skills. The interdisciplinary character of such kinds of interaction is increasingly indebted to collaborative team teaching activities, which not only provide successful linguistic training, but also increases students' professional knowledge as they learn English for a specific purpose represented by studying subject matter. The main challenge of ESP teachers is their lack of subject knowledge germane to their ESP course, such as terminology and subject philosophy.

An interdisciplinary approach to the teaching and learning of engineering communication is known in foreign and 
domestic didactic pedagogy (Artemeva et al., 1999). Foreign and domestic methodists note that the specificity of ESP teaching requires a close relationship between foreign language and professional subject disciplines. Entrepreneurship skills are being increasingly recognized as important skills for engineering graduates.

Co-teaching (team teaching) is one of the options of this approach in practice (Austin and Baldwin, 1991; Gray and Halbert, 1998). Many terms have been used to identify co-teaching, including team teaching, collaborative teaching, and cooperative teaching. The term team/collaborative teaching (literally: "teaching in team"/ "cooperative teaching") in a broad sense indicates the interaction of a team of teachers with a view toward effective learning (Friend and Cook, 2000). In a more narrow sense, the term means the co-teaching of two or more teachers training within the same class, or an "adjunct model" of team teaching that means teaching of parallel courses in the same group of students. "Co-teaching is a model that emphasizes collaboration and communication among all members of a team to meet the needs of all students (Cook and Friend, 1995a)." In some instances, "team teaching" is considered a subset of co-teaching (Cook and Friend, 1995a, b), and in other cases it denotes co-teaching itself (Jones and Carlier, 1995). Dudley-Evans and St John (Dudley-Evans and St. John, 1998) consider team teaching with two teachers present in an ESP class as the final level of subject-language integration.

The nature of "interdisciplinary team teaching" suggests doing something that can't be done individually and is not always initiated by a single subject. Davis states that, "the ideal interdisciplinary course begins with a great idea that can come from anywhere. Once the course is established that idea grows and the course takes on a life of its own (Davis, 1997)." The participation of a discipline-specific teacher in ESP teaching has been given attention for obvious reasons:

1. ESP teachers are almost always teachers of English for General Purposes and their switch into this field is sudden (Strevens, 1997).

2. To teach ESP, a language teacher has to know both the content of the technical science, on the basis of which the ESP teaching is organized, and the communication skills necessary for the future engineers.

3. A language teacher cannot find practical solutions to the problems that he or she will face when teaching ESP course, because he or she should understand the role of the technology in the economy, its status in the present period, and the prospects for its development.

4. It should be noted that professional language with its inherent terminology is a special language that is understandable only to professionals. A language teacher is not sufficiently familiar with those terms and topics of technical language.

\section{Team Teaching Model}

Within the framework of various projects by researchers proved the effectiveness of the work of the teachers in both bilingual (learning a foreign language), and in an interdisciplinary integrated learning (foreign language teaching for special purposes) (Bronstein, 2003; Chamberlain, 1980). Benefits are reported when language teachers collaborate among themselves or when language teachers and discipline-specific teachers of some other disciplines collaborate in teaching. The most commonly mentioned benefits are increased student motivation and interest to ESP teaching by content and matters of delivery. With respect to the former type of collaboration Hanson \& Hammer stress that team teaching reduces the gap between science and language (Hansen and Hammen, 1980).

A two-year integrated ESP curriculum, so-called "team teaching model", was implemented in National Research Tomsk State University (TPU), Russia, in 2003 (see Table 1).

Table 1. Sample of TPU team teaching model for two educators

\begin{tabular}{|l|l|}
\hline Teacher $\mathbf{A}$ & Teacher $\mathbf{B}$ \\
\hline English Language & Biotechnology Studies \\
\hline English Language & Materials Science Studies \\
\hline English Language & Material Cutting and Cutting Tools Studies \\
\hline English Language & Nanomaterial and Nanotechnology Studies \\
\hline English Language & Laser Technology Studies \\
\hline
\end{tabular}

It covers a third- and fourth-year ESP course. A traditional ESP course curriculum of the first- and second-year course is further transferred to the field of interdisciplinary ESP course, and "individualistic teaching methods accordingly transformed into team teaching (Jang, 2001)." As a result, the implementation of the two-year integrated ESP team teaching curriculum differs from the long-existing practice of the English language teaching in many universities in 


\section{Russia.}

As used in this paper, team teaching refers to the interactive involvement of a language teacher and a disciplinespecific teacher. The objective of this type of collaboration is to increase the relevance of a foreign language and allow engineering students a chance to use it in an area of interest of them, while bringing a more international perspective to the subject studies (Stryker and Leaver, 1997).

The team teaching model, applied in TPU, consists of three levels of teachers' integration: co-operation, collaboration and team teaching. Table I lists a brief description of the format of the co-work of a language teacher and a discipline-specific teacher.

Before starting the ESP course teaching of the same students at different time (two-stage educational process), a discipline-specific teacher and a language teacher in co-operation discuss their perspectives of teaching as an effective team; plan content and language objectives for ESP course, teaching time for each stage. The co-planning process encourages two teachers to bounce ideas off each other for teaming. ESP curriculum based on students' needs and English language skills is an initial starting place for making specific team teaching, sharing responsibilities and ensuring all students understand and complete academic activities. The key characteristic of this model is that, on the one hand, it is associated with the individual subject area; while on the other hand, it is an integral part of ESP course.

Table 2. Team teaching model in TPU

\begin{tabular}{|l|l|}
\hline Forms of teachers' integration & Activities \\
\hline Co-operation & $\begin{array}{l}\text { Learning students' target situation needs; syllabus agreement; planning coordination; } \\
\text { choosing teaching materials for co-operation teaching; evaluation of materials; grading; } \\
\text { discussing behavior management in the ESP course. }\end{array}$ \\
\hline Collaboration & $\begin{array}{l}\text { Definition of goals; specifying teaching methods; sharing materials; discussing feedback } \\
\text { problems; developing evaluation management. }\end{array}$ \\
\hline Team teaching & Each teacher focuses on his or her field and acts separately in a single class. \\
\hline
\end{tabular}

The team teaching model in TPU is adopted in two stages in an integrated manner:

In the first stage, a language teacher prepares engineering students to practice in a real engineering discourse communication, trained by the discipline-specific teacher in the second stage, through the development of students' technical language and communicative skills, i.e. listening, reading, and writing skills, as well as providing them with glossaries and specific vocabulary related to the selected topics and related problem based tasks that will be discussed in the second stage, as well as English grammar in order to expand students' knowledge about some specific linguistic aspects in ESP. The selection of teaching materials presented to the students is based on learners' needs and professional interests. Both teachers analyze whether the selected topics exhibit professional unity and whether students' knowledge of the topics presented match their training or not. In this sense, cooperation between a language teacher and a discipline-specific teacher leads to collaboration. A language teacher classifies the selected teaching materials according to the degree of linguistic difficulty, as well as the overall cohesion of the content matter of a specific discipline. Mastery of the necessary linguistic competence will allow students to use language skills freely in the second stage.

In the second stage, the leading role belongs to a discipline-specific teacher with good mastery of English language. The aim of this teacher is to devote majority of class time to the development of oral and aural students' skills. This stage of the team teaching process aims to develop communicative competence on the basis of professional subject content. It allows the students to see relationships between English and specific subject, as they didn't get to see before in the first-and second-year course.

The two-teacher team is used in the third- and fourth- year course of TPU students as a sound transition from a single-teacher, self-contained classroom in the first- and second- year course of students

Thus TPU two-teacher team model involves an English teacher and a discipline-specific teacher in the planning of ESP course: its preparation, presentation, and evaluation of students learning outcomes

The model of the two-teacher team is developed in accordance with the methodological approach of the formation, development, and improvement of engineering students' communicative competence. In addition, a student is given the opportunity to see the significance of a foreign language in the context of his or her future professional activities.

All discipline-specific teachers need international or TPU foreign language certification allowing them to teach ESP course. TPU language certification is based on the model of Cambridge international certificate. Team-teaching is increasingly identified as a key aspect in teachers' professional growth. In the period from 2003 to 2014 the total amount of TPU foreign language certification holders among the discipline-specific teachers equals 413 (see Table 3). Obtained 
data demonstrate a very high interest of discipline-specific teachers towards language learning. In addition, a good command of a foreign language contributes to its further implementation in professional and science areas.

Table 3. Language level of TPU foreign language certification holders among discipline-specific teachers

\begin{tabular}{|l|c|c|c|c|c|}
\hline & \multicolumn{5}{|c|}{ Time period: $2003-2014$} \\
\cline { 2 - 6 } & \multirow{2}{*}{ Total number of exam takers } & \multicolumn{4}{|c|}{ Language level/Number of exam passers } \\
\cline { 3 - 6 } & 413 & C1 & B2 & B1 & $<$ B1 \\
\hline Discipline-specific teachers & 413 & 32 & 255 & 96 & 30 \\
\hline
\end{tabular}

Nevertheless, many aspects of ESP team teaching are left problematic. In the pedagogical seminars prepared and carried out for ESP teachers by the authors of this paper, the following challenges in the process and practice of team teaching were encountered:

- lack of awareness of the need to work together;

- substantial time (man hours) spent on the preparation to team-teaching;

- problems in the practice of team teaching (most participants of those pedagogical seminars had such challenges);

- differences in personal and professional philosophy towards each other and the students;

- teachers' lack of interest in cooperation and learning each other's teaching style.

These challenges do not mean that team teaching must take more time, but initially the time must be dedicated to create co-work lesson plans.

All the challenges mentioned above illustrate that this is not an easy task to put team-teaching model into practice. Resistance to a team teaching model can occur, because teachers are often considered to be autonomous. The participants of team teaching should hold a positive attitude towards the subject areas involved in ESP course. They ought to be willing to cooperate with each other.

\section{Findings}

Findings are discussed in the areas of achievement effective outcomes of the students taught by two teachers (a team teaching approach) in comparison with the one English teacher self-contained classroom (a traditional approach) of ESP course.

Table 4 presents detailed information on academic and research progress of students receiving traditional ESP course teaching (engineering students of the first- and second-year course students, they entered TPU in 2010 and passed their final test in English in 2012) and ESP course team teaching (engineering students of the third- and fourthyear course choosing ESP course in 2012 and passing their final test in 2014).

Table 4. Assessing students' academic and research achievement progress

\begin{tabular}{|c|c|c|c|}
\hline \multirow[t]{2}{*}{ Criterion } & \multirow[t]{2}{*}{ Activities } & \begin{tabular}{|c|} 
Traditional teaching \\
Total number of $1-2$ course \\
students (2012 year) \\
\end{tabular} & $\begin{array}{c}\text { Team teaching } \\
\text { Total number of } 3-4 \text { course } \\
\text { students ( } 2014 \text { year) }\end{array}$ \\
\hline & & 3848 & 1324 \\
\hline 1.Students' academic results & Formative assessment results (70 points and above) & $1487(38.6 \%)$ & $655(49.4 \%)$ \\
\hline \multirow{4}{*}{$\begin{array}{l}\text { 2.Practical application of a foreign } \\
\text { language in studies and research }\end{array}$} & Participation in academic mobility programs & $42(1.1 \%)$ & $108(8.2 \%)$ \\
\hline & Participation in scientific conferences & $49(1.3 \%)$ & $83(6.3 \%)$ \\
\hline & Publication of scientific papers & $45(1.2 \%)$ & $99(7.5 \%)$ \\
\hline & Participation in international projects (grants) & $22(0.6 \%)$ & $39(3 \%)$ \\
\hline
\end{tabular}

The third- and fourth-year course students improved their academic skills completing successfully ESP course. The number of the students who managed to get 70 points and above, out of possible 100 points, increased in $10.8 \%$ in comparison with the first- and second-year course despite the number of students of the third- and fourth-year course decreased in 34\% (see Table 4). As shown above the average final exam scores of the students taught by two teachers were higher than those of students receiving traditional English teaching.

Moreover, some progress of the third-and fourth-year course students from 2012 to 2014 extends in English language activities beyond the classroom. Table IV demonstrates the third-and fourth-year course students' contribution 
in science as well. Table 4 indicates the main differences in the number of published papers $(>6.3 \%)$, science conference participants (>5\%), academic mobility program participants (>7.1\%), international projects participants $(>2.4 \%)$.

The results show the positive influence of team teaching over traditional ESP teaching even though the team teaching scores were higher in all of the comparison of students' achievements.

\section{Conclusion}

The philosophy of the two teachers working together is considered to be very important to teach ESP course (Lee, 2000; Tajino and Tajino, 2000). The progression from cooperation to collaboration and to team-teaching is not only advisable, but a logical process. The model of ESP team, as developed by TPU, is considered to be effective and efficient, nevertheless its challenges mentioned above.

Successful cases have displayed a number of team teaching benefits:

1. It meets the actual learners' needs and interests.

2. Students can gain links between language skills and specific professional knowledge. It increases students' motivation and interest.

3. It develops students' communicative competence boosting their academic, professional and research skills.

4. Collaboration between a language teacher and a discipline-specific teacher gives the opportunity to a language teacher to learn more about the engineering, including a conceptual approach. Meanwhile, a content teacher can become more aware of a foreign language use.

5. Teaching methods and communicative approaches used by both teachers can provide a new pedagogical experience for both of them.

Team teaching is considered to be a beneficial experience for all members of the team involved in the process. The model of ESP team teaching in TPU has its definite structure. Both an English language teacher and a disciplinespecific teacher aim to improve the quality of teaching and learning. Thus, practical advantage of the described model of ESP team teaching appears to be another avenue to be explored in the Russian universities for its benefits to both students and teachers.

\section{References}

Artemeva, N., Logie, S., \& St-Martin, J. (1999). How Theories of Genre and Situated Learning Help Introduce Engineering Students to Discipline-Specific Communication. Technical Communication Quarterly, vol. 8, no. 3, pp. 301-316.

Austin, A. E., \& Baldwin, R. G. (1991). Enhancing the quality of scholarship and teaching. ASHE-ERIC Higher Education Report No. 7. Washington, DC: George Washington University, School of Education and Human Development.

Bronstein, L.R. (2003). A model for interdisciplinary collaboration. Social Work, 48(3), 297-304.

Challenges of Higher Technical Education (2001). University Proceedings, Novosibirsk, NSTU, vol. 20, 93 p.

Chamberlain, R. (1980). The SP of the E. In Team teaching in ESP (pp.97-108). London: The British Council.

Cook, L., \& Friend, M. (1995a). Co-teaching: Guidelines for creative effective practices. Focus on Exceptional Children, vol. 28(3), pp. 116.

Cook, L., \& Friend, M. (1995b). Principles for the practice of collaboration in schools. Preventing School Failure, vol. 35(4), pp. 6-9.

Crebet, G., Bates, M., Bell, B., Patrick, C.J., \& Cragnolini, V. (2004). Ivory tower to concrete jungle revisited. Journal of Education and Work, vol. 17 (1), pp. 47-70.

Davis, J. R. (1997). Interdisciplinary Courses and Team Teaching. Phoenix: American Council on Education, Oryx Press Series on Higher Education.

Dudley-Evans, T., \& St. John, M. J. (1998). Developments in ESP: A multi-disciplinary Approach. Cambridge, UK: Cambridge University Press.

Friend, M., \& Cook, L. (2000). Collaboration skills for school professionals (3rd ed.). White Plains, NY: Longman.

Gray, T., \& Halbert, S. (1998). Team teach with a student: New approach to collaborative teaching. College Teaching, vol. 46(4), pp. $150-153$.

Hansen, A. G., \& Hammen, D. L. (1980). The English teacher and the camera - team teaching for special purposes. In Team Teaching in ESP (ELTDocuments 106), pp. 92-96

Jang, S. J. (2001). The inquiry for models of team teaching. Educational Research and Information, vol. 9(4), pp. 66-82.

Jones, M. M., \& Carlier, L. L. (1995). Creating inclusionary opportunities for learners with multiple disabilities: A team-teaching approach. Teaching Exceptional Children, vol. 27, pp. 23-27.

Lee, C.F.K. (2000). About co-teaching an English for Specific Purposes (ESP) workshop: An English teacher's reflections. Teaching and Learning 21(1), 18-26.

Strevens, P. (1997). The learner and the teacher of ESP. ESP in the Classroom: Practice and Evaluation: (ELT Documents 128). London: Modern English Publications in association with British Council, pp. 39-44. 
Stryker, S., \& Leaver, B. L. (1997). Content-Based Instruction in Foreign Language Education. Washington D. C.: Georgetown University Press.

Tajino, A., \& Tajino, Y. (2000). Native and non-native: what can they offer? Lessons from team-teaching in Japan. ELT Journal, 54(1), 311. 